\title{
COMPARISION OF CURCUMIN NANOEMULSION DROPS SIZE BETWEEN HOMINIZATION AND ULTRASONICATION SUPPORTING
}

\author{
HO THI THANH THUY ${ }^{1}$, PHAM THI KIM NGOC ${ }^{1}$, NGUYEN THI THANH TU, \\ HUYNH THI THANH TRUC, NGUYEN VAN HAI ${ }^{1}$, TRAN QUANG HIEU ${ }^{1,2^{*}}$ \\ ${ }^{1}$ Faculty of Food Technology-Saigon Technology University \\ ${ }^{2}$ Basic Science Department-Saigon Technology University \\ hieugodau78@gmail.com
}

\begin{abstract}
In this paper, curcumin nano-emulsions were successfully prepared by combining hominization and ultra-sonication methods which have been mentioned. The optimal conditions for the hominization method have been established as follows: $3 \%$ emulsifier concentration, $20,000 \mathrm{rpm}$ of capacity in 60 minutes, the average size of nano drops was $78 \mathrm{~nm}$. Meanwhile, the optimal conditions of the ultrasonic method are also constructed as follows: $2 \%$ emulsifier concentration, $450 \mathrm{w} / \mathrm{g}$ of ultrasonic power, $20 \mathrm{kHz}$ frequency, the average size of the droplet was $58 \mathrm{~nm}$. Nano-emulsion system has been stable after 4 months of cold storage.
\end{abstract}

Keywords. nano emulsion, curcumin, hominization, sonication.

\section{INTRODUCTION}

Curcumin, a natural yellow phenolic compound, is present in Curcuma longa Linn (turmeric). It is a natural antioxidant and has shown many pharmacological activities such as anti-inflammatory, antimicrobial, anti-cancer, and anti-Alzheimer in both preclinical and clinical studies. Moreover, curcumin has hepatoprotective, nephroprotective, cardioprotective, neuroprotective, hypoglycemic, and antidiabetic activities and it also suppresses thrombosis as well as protects against myocardial infarction [1]. Nanotechnology is increasingly considered to be the technology of the future. Among the wide applications of nanotechnology is the use of nanoparticles for enhancing the bioavailability and the solubility of lipophilic compounds such as curcumin in drug delivery systems. Therefore, applying nanoparticles gained immense popularity in the last decade due to their potential to improve the therapeutic effects ofencapsulated drugs by protecting drugs from enzymatic degradation. Providing their controlled release and prolonged blood circulation, changing their pharmacokinetics, decreasing their toxicity, and limiting their nonspecific uptake [2,3]. Over a period of time, numerous emphases have been given to develop the biodistribution of natural curcumin, but it is only just recently that the application of the field of nanotechnology has considerably enhanced its therapeutic effects. Nanoparticles such as liposomes [3], micelles[4], nanogels [5], niosomes [6], cyclodextrins [7], dendrimers[8], chitosan [9], and solid lipids[10] are emerging as one of the useful alternatives that have been shown to deliver therapeutic concentrations of curcumin. The use of the above nanoparticle has improved main problems of curcumin such as low solubility, instability, poor bioavailability, and rapid metabolism in cancers, wound healing, Alzheimer's disease, epilepticus, ischemia diseases, inflammatory diseases. In this work, we prepared nano-emulsions with the support of surfactant Tween 80 and two ultrasound and hominization techniques that were also used to enhance the dispersion of curcumin in water solvents.

\section{MATERIALS AND METHODS}

\subsection{Chemicals and equipment}

All used chemicals and solvents were in analytical grade and were used without further purification unless otherwise mentioned. Doubles distilled and degasifier water was used throughout. Ethanol 960 
(v/v), Acetone, Ethyl acetate, DPPH (2,2-diphenyl-1-picrylhydrazyl), Trolox (6-hydroxy-2,5,7,8tetramethylchroman-2-carboxylic acid), Curcumin and Silica gel were purchased from Sigma-Aldrich Pty Ltd.

Yamato RE301 vacuum rotary evaporator, VCX 750 Ultrasound System, IKA T 25 digital ULTRATURRAX®, UV-Vis Spectrometer, Thermo Genesys 10S UV-Vis and HLPC/MS Agilent 1260 with UVAgilent probe have been used in this research.

\subsection{Preparation of turmeric extract}

Curcumin was extracted from turmeric with the aid of ultrasound that was reported in previous work [12]. The optimal extraction process of curcumin had been formulated from the following specifications: solvent for the extraction process was $100 \%$ alcohol 960 , the proportion of ingredients/solvent was $1 / 50$, extraction time was 60 minutes, extraction temperature was $60^{\circ} \mathrm{C}$, the ultrasonic power for extraction was $300 \mathrm{~W} / \mathrm{g}$ TP and the optimum ultrasonic time was 90 seconds. The extract was filtered and concentrated using a rotary evaporator under reduced pressure to increase the curcumin content (20 brix). Final curcumin content in the turmeric extract was measured using HPLC analysis.

\subsection{Preparation of turmeric nanoemulsions}

To prepare the nanoemulsions, the oil phase was first prepared by dissolving $2 \%$ (v/v) turmeric extract in sachi oil. The aqueous phase was prepared by mixing Tween 80 with distilled water. The mixture was subjected to magnetic stirring at $60^{\circ} \mathrm{C}$ for $1 \mathrm{~h}$ to obtain a coarse emulsion. Nanoemulsions were then prepared by further homogenizing the coarse emulsion. The mixture was subjected to high-speed homogenization at 5,000-25.000 rpm for 10 mins or to ultrasonication (US) with a Vibra Cell (VCX-750, Sonics \& Materials, Inc., USA) operated at $750 \mathrm{~W}$ and $40 \%$ amplitude for 10 mins.

\subsection{Determination of curcumin content}

To determine the curcumin content, the sample was diluted in methanol, vortex and filtered through a $0.45 \mu \mathrm{m}$ membrane filter for HPLC analysis. A high-performance liquid chromatograph (Agilent 1260 HPLC) fitted with a UV absorbance detector and an Eclipse Plus C18 column $(4.6 \times 250 \mathrm{~mm}, 5 \mu \mathrm{m}$; Agilent) was used. The mobile phase was acetonitrile and $2 \%$ acetic acid (70:30, v/v), pumped at a flow rate of $0.8 \mathrm{~mL} / \mathrm{min}$. A sample volume of $20 \mu \mathrm{L}$ was injected, and the detector was operated at $465 \mathrm{~nm}$.

\subsection{Determination of efficiency formation curcumin nanoemulsion $(\mathrm{E} \%)$}

The calculation of curcumin content in nanoemulsions was performed by a direct method as previously described by $\mathrm{H}$. Rachmawati et al.,[13]. The nanoemulsion was centrifuged at 14,000 rpm for 20 mins and $5 \mathrm{~mL}$ of DMSO was added to $10 \mu \mathrm{L}$ of supernatant to extract the curcumin. Curcumin concentration was then measured using an HPLC-UV (Agilent 1260). The efficiency formation curcumin nanoemulsion was calculated using the following equation:

$$
\% \mathrm{E}=\mathrm{A}-\mathrm{Ad} / \mathrm{A}
$$

A: Total amount of curcumin applied in preparing nanoemulsion

Ad: Amount of curcumin was extracted into DMSO

\subsection{Determination of nano-emulsion stability}

The most common method to evaluate the stability according to previous researches is the thermal stress test. To experience the inseparability of the system, we have also carried out a centrifugal stress test at $3500 \mathrm{rpm}$ for 30 minutes of the samples which were stored at $10^{\circ} \mathrm{C}$. This stability test procedure is similar to that mentioned by Bernardi with the study on nano-emulsions of rice bran oil. Moreover, the stability of nano-emulsions was studied by the changes in mean droplet diameter throughout 120 days of storage at $15^{\circ} \mathrm{C}$.

\subsection{Particle size measurements}

The mean droplet diameter (Z-averages) and particle size distribution of the curcumin nano-emulsions were measured using a dynamic light scattering instrument (SZ-100, HORIBA Ltd., Japan). Due to the 
transparency of the final nano-emulsion systems, the measurements were performed by the intensity-time fluctuations of the laser beam scattered from the samples at $25^{\circ} \mathrm{C}$ and an angle at $90^{\circ}$. The samples were maintained as the initial state to avoid indetermination of the droplet in systems when the concentration of the system was extremely diluted.

\subsection{Transmission electron microscopy (TEM)}

The particle size and droplet shape nano-emulision were determined by transmission electron microscopy (TEM; HT 7700, Hitachi, Ltd., Japan). The samples were diluted 10-fold, and a drop of the diluted sample was applied onto a carbon-coated 300-mesh copper grid, which was kept under ambient conditions for $30 \mathrm{~s}$. Phosphotungstic acid was applied to the grid for $10 \mathrm{~s}$ as a negative staining agent, and the grid was then dried overnight and imaged.

\section{RESULTS AND DISCUSSION}

\subsection{Effect of concentration surfactant Tween 80}

According to McClements, DJ 2010 [16], the formation of nanoparticles in the emulsion system depends on the dispersion rate of the emulsion system (the time of adsorption of the emulsifier on the surface to divide and collide between droplets together). As the Tween 80 concentration increases, the dispersion rate also increases, the emulsifier will quickly adsorb to the dividing surface to form a layer around the particles before the collision between the droplets. The system occurs and forms particles of small size. In addition, the effect of forming particles of small size depends on the rheological properties of the grain and the surrounding environment. The study of Kentish, S et al 2008 [14], indicated that the viscosity ratio of the continuous dispersion phase in the appropriate range will better support the formation of 54 nanoparticles.

Table 1: Mean of nanocurcumin drops size at different Tween concentrations

\begin{tabular}{ccc}
\hline $\begin{array}{c}\text { Concentration } \\
(\%, \mathrm{w} / \mathrm{v})\end{array}$ & $\begin{array}{c}\text { Hominization method } \\
(\mu \mathrm{m})\end{array}$ & $\begin{array}{c}\text { Ultrasound method } \\
(\mu \mathrm{m})\end{array}$ \\
\hline 0.5 & $20.0263 \pm 0.095^{\mathrm{a}}$ & $15.2262 \pm 0.097^{\mathrm{a}}$ \\
1 & $11.9255 \pm 0.230^{\mathrm{b}}$ & $6.5169 \pm 0.131^{\mathrm{b}}$ \\
2 & $9.5789 \pm 0.108^{\mathrm{d}}$ & $2.8208 \pm 0.007^{\mathrm{c}}$ \\
4 & $9.0657 \pm 0.209^{\mathrm{e}}$ & $0.1138 \pm 0.004^{\mathrm{e}}$ \\
${ }_{-}$In the same column, different values indicate differences according to the columns $(p<0.05)$ & $0.4191 \pm 0.008^{\mathrm{d}}$ \\
\hline
\end{tabular}

The average size of nano-curcumin at different concentrations of Tween 80 was shown in Table 1 and Figure 1. The data showed that the size of nano-curcumin particles tends to decrease when the concentration of Tween 80 increases. The nano drops size of hominization method decreases from $20,0263 \mu \mathrm{m}$ to $9,0654 \mu \mathrm{m}$ and nano drops size of the ultrasonic method decreases from $15.2262 \mu \mathrm{m}$ to $0.1138 \mu \mathrm{m}$. The results also showed that the ultrasonic method was more effective in reducing the size of the particles in the system, reducing nearly 80 times $(0.1138 \mu \mathrm{m}$ compared to $9.0657 \mu \mathrm{m})$ compared to the assimilation method at the same concentration Tween 80 was 3\%. When increasing Tween to $4 \%$ concentration, the average particle size tends to increase. Therefore, the optimal tween concentration for both methods was $3 \%$. 


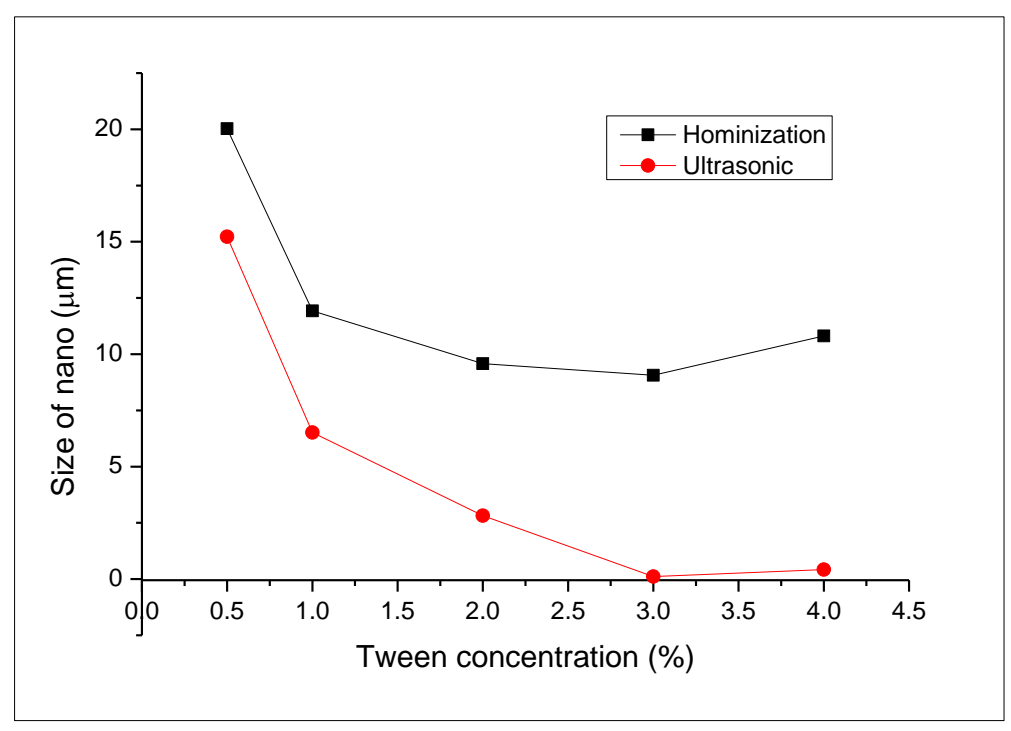

Figure 1. Diameter of nano emulsion at differences of Tween concentraions

The results of our research are quite consistent with the data from other scientists. For example, nanocurcumin obtained from Kentish, S. research, also reached the average particle size of $0.135 \mu \mathrm{m}$ at $5 \%$ Tween 40 concentration in $400 \mathrm{~W}$ ultrasonic capacity, frequency of $20 \mathrm{kHz}$. The study of Ahmed, K. et al. 2012 , for the average size of nano-curcumin reached $0.174 \mu \mathrm{m}$ at the concentration of emulsifiers (lipids) of $10 \%$ (w / v). The study of D. Shailendiran et al., 2011 [17], for the average particle size reached $0.120 \mu \mathrm{m}$ with $\underline{5}$ minutes of ultrasound conditions. Another study by Sari. T. P and coworkers 2015, an emulsion system of $0.04 \%$ CUR with a mixture of $2 \%$ Tween 80 and $0.5 \%$ whey protein concentrate 70 in ultrasonic conditions at $4{ }^{\circ} \mathrm{C}$ in 15 minutes was carried out and reached the average particle size of $0.141 \mu \mathrm{m}[18]$.

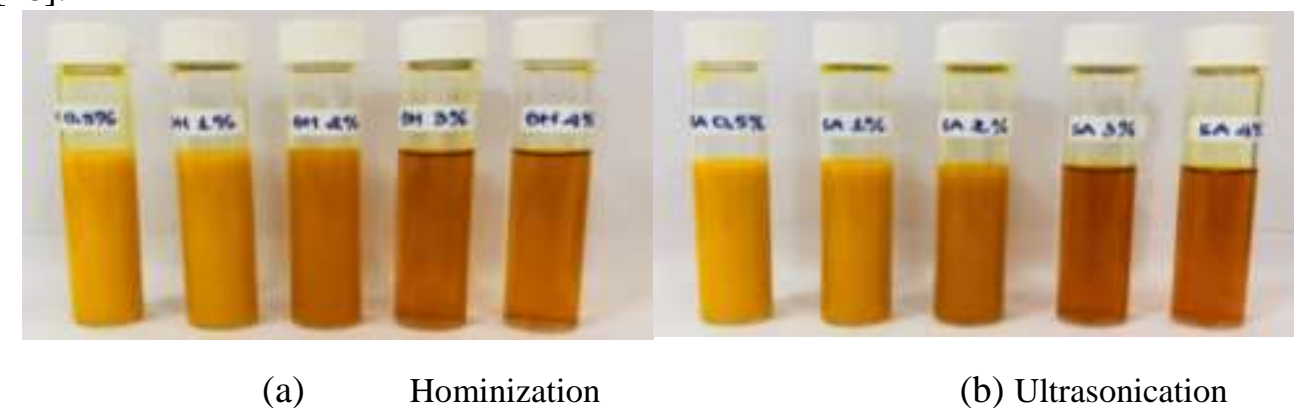

Figure 2. Nano curcumin emulsion at Tween concentrations difference

\subsection{Effect of capacity to nano drops size}

The influence of equipment capacity on the process of creating nano-curcumin was presented in Table 2 and Figure 3. For the hominization method, when the rate increases from 5,000 to 20,000 rounds/min, the average particle size tends to decrease sharply from $9.067 \mu \mathrm{m}$ to $0.619 \mu \mathrm{m}$. This could explain that when the hominization rate increased, intermolecular bonds in both solvents and dispersants were cut off and substances were easily distributed to each other and formed new systems with smaller dimensions and more stable surface energy.

Our results were better than other studies using the hominization method. For example, the study of Wang, X., J and colleagues 2008 at the rate of $<13,000 \mathrm{rpm}$, the emulsion system was unsustainable and phase separation after 24 hours of storage and large size 2-20 $\mu \mathrm{m}$ [20]. Another study by Giang P.V et al., 
2013 at the speed of $18,000 \mathrm{rpm}$ for 15 minutes, the particle size only reached $0.269 \mu \mathrm{m}$.

Table 2: Mean of nano curcumin drops size at differences capacity

\begin{tabular}{cccc}
\hline $\begin{array}{c}\text { Capacity } \\
(\mathrm{rpm})\end{array}$ & $\begin{array}{c}\text { Hominization method } \\
(\mu \mathrm{m}))\end{array}$ & $\begin{array}{c}\text { Capacity } \\
(\mathrm{W} / \mathrm{g})\end{array}$ & $\begin{array}{c}\text { Ultrasound method } \\
(\mu \mathrm{m})\end{array}$ \\
\hline 5.000 & $9.067 \pm 0.014^{\mathrm{a}}$ & 150 & $0.419 \pm 0.002^{\mathrm{a}}$ \\
10.000 & $1.934 \pm 0.006^{\mathrm{b}}$ & 300 & $0.088 \pm 0.001^{\mathrm{b}}$ \\
15.000 & $1.253 \pm 0.013^{\mathrm{c}}$ & 450 & $0.058 \pm 0.002^{\mathrm{d}}$ \\
20.000 & $0.619 \pm 0.001^{\mathrm{d}}$ & 600 & $0.076 \pm 0.001^{\mathrm{c}}$ \\
\hline
\end{tabular}

In the same column, different values indicate differences according to the columns ( $p<0.05)$
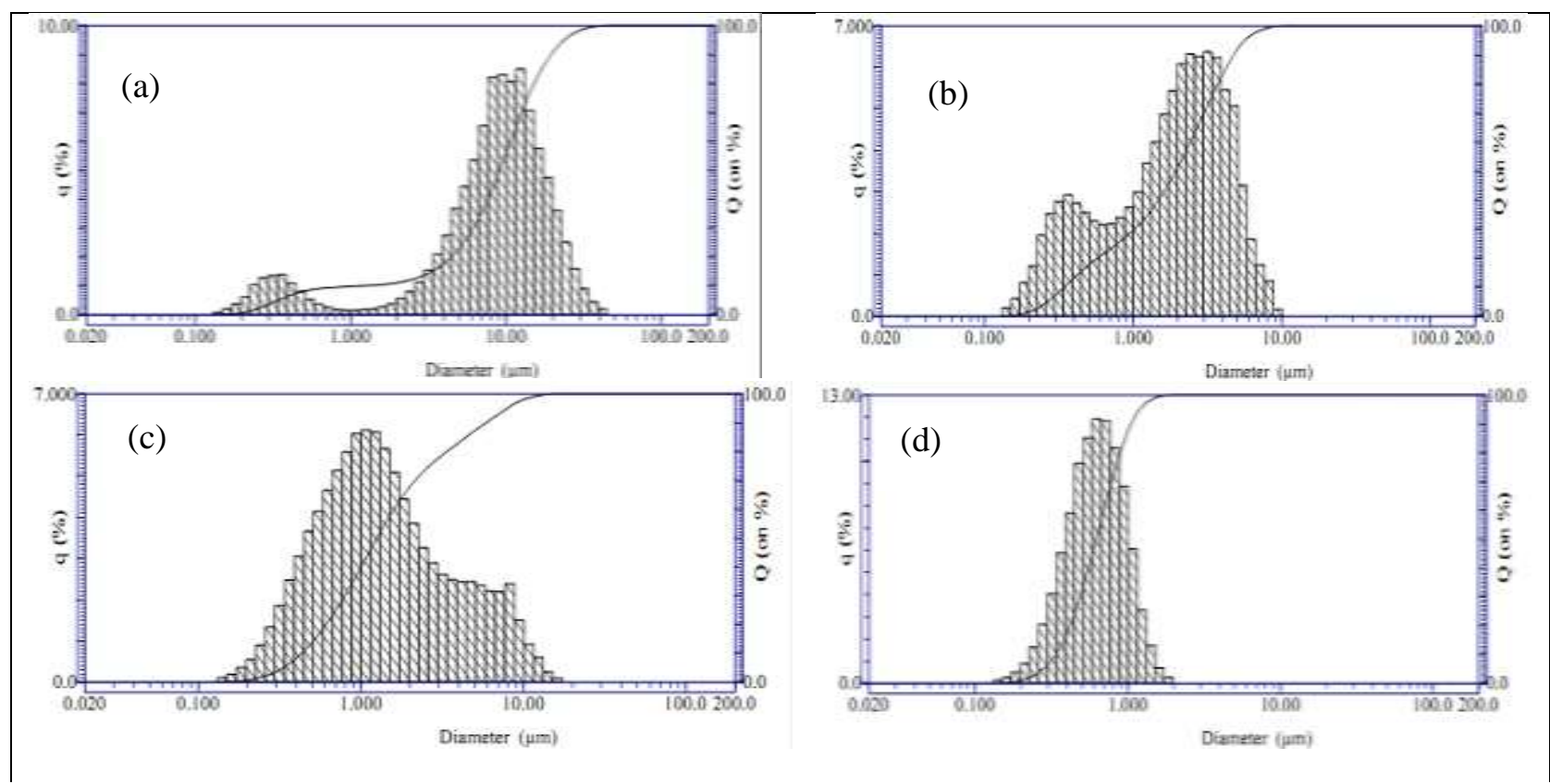

Figure 3. Average particle size distribution at the hominization capacities: 5,000 rpm (a), 10,000 rpm (b), $15,000 \mathrm{rpm}(\mathrm{c})$ and 20,000 rpm (d)

The results also showed that the ultrasound method is suitable for creating nano-emulsion. Figure 4 indicated that drops size depends heavily on ultrasonic capacity. The average size of drops decreased significantly from $0.419 \mu \mathrm{m}$ to $0.058 \mu \mathrm{m}$ when the capacity increases from 150 - 450W/g. According to 1978's Li \& Fogler, the reason could be explained that low-frequency $(20-100 \mathrm{kHz})$ ultrasound waves exert a strong effect on the surface that divides between the two phases, making it unstable leading to the explosion of dispersed phase (oil phase) in continuous phase (water phase); In addition, the air bubbles (cavitation) in the liquid environment (gas invasion) through each cycle (-) and cycle (+) appears. At that time, the dispersed particles in the continuous phase are increasingly divided into the smallest [15]. However, the average particle size of $600 \mathrm{~W} / \mathrm{g}$ has an increasing tendency $(0.076 \mu \mathrm{m})$. This result is also consistent with the study of Kentish, S., and colleagues [14]. This can be explained by the high ultrasonic power for a certain period time, the "cavitation" bubble explosion reaches critical and saturated point. At that time, the air bubbles formed not much and had only the main stirring. The emitted ultrasonic energy (Bjerknes energy) is increased to push the emulsion particles to enter junctions and collide with each other to recreate larger sized particles according to Pangu \& Feke in 2004 [17]. 


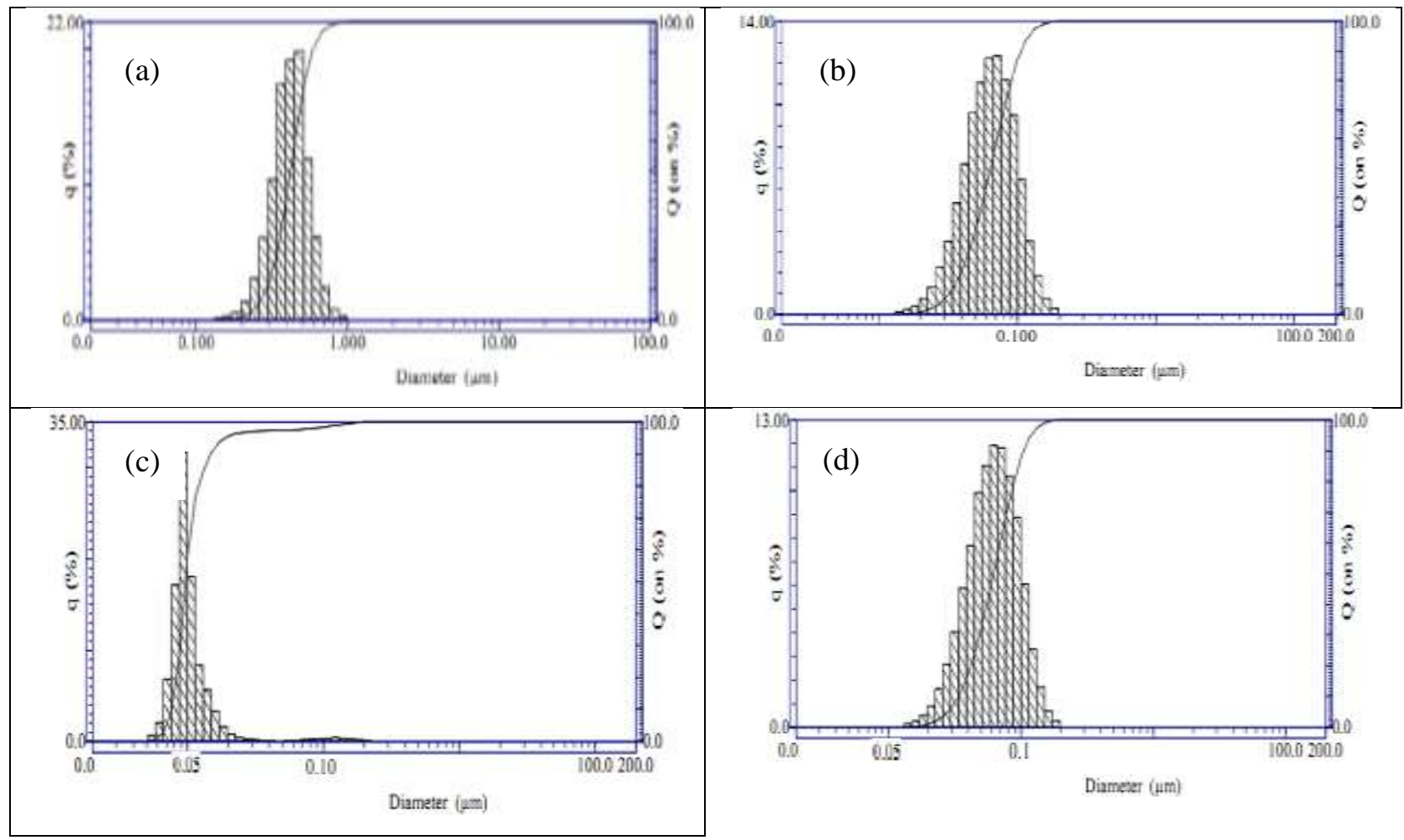

Figure 4. Average particle size distribution at the ultrasonic capacities: 150W/g (a), $300 \mathrm{~W} / \mathrm{g}$ (b), 450W/g (c) and $600 \mathrm{~W} / \mathrm{g}(\mathrm{d})$

The morphology of curcumin nanoemulsions using transmission electron microscopy (TEM) was shown in Figure 5. Observation of nanoemulsion by TEM imaging is likely the best method to study specimen' morphology, purity and particle size distribution in non-solid disperse systems. As presented in Figure 5, the spherically oil drops were monodispersed with uniform particle size, confirming the particle size in Table 1 which was measured by using a dynamic light scattering instrument.

Figure 5. Transmission electron microscopy (TEM) analysis of curcumin nanoelmusion

\subsection{The efficiency of nano formation}

Nano-forming efficiency was calculated according to the formula in section 2.5. The results showed that nano-elmusion production efficiency was quite high. The efficiency of the hominization method at $20,000 \mathrm{rpm}$ reached $72.4 \pm 5.0 \%$, while the efficiency of the ultrasonic method was $87.5 \pm 7.5 \%$.

\subsection{Nano-emulsion stability}

The impact of storage time on the stability of a representative nano-emulsions: $0.5 \%$ curcumin, $2 \%$ coconut oil, and 3\% Tween 80 were examined. Figure 6 represents the droplet size of the emulsion at the beginning and that after 4 months. The results in Figure 6 suggested that the mean droplet diameter did not increase during storage time (during 4 months) and even has tended to get smaller. Droplet size measurements were a good indicator of the formulation stability. It should be noted that, after a certain time, the droplet diameter remained stable. Figure 7 indicated that the nanosystem was stable at $\mathrm{pH}$ values from 3 to 7 . 


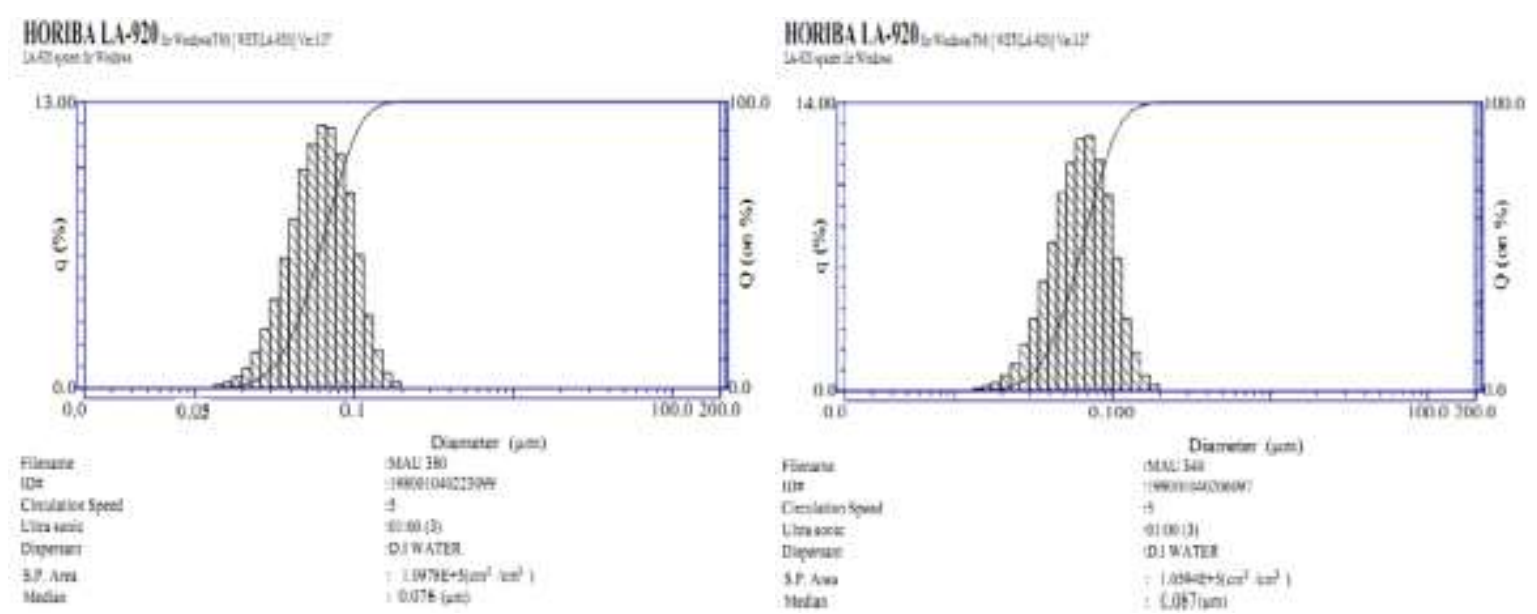

Figure 6. Droplet size of nano curcumin emulsions before and after 4 months stored at $15 \mathrm{oC}$.

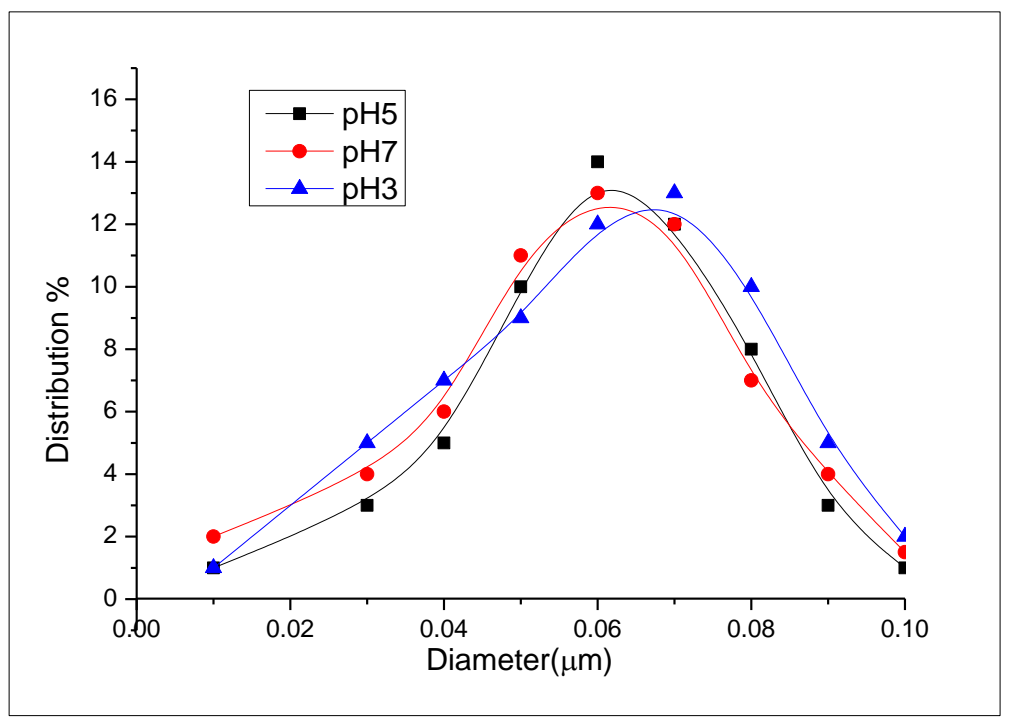

Figure 7: Distribution of system size of curcumin nano at different $\mathrm{pH}$

\section{CONCLUSIONS}

After a period of research on preparing nano curcumin by two methods, we found that the ultrasonic method gave the size of the system smaller than the hominization method. However, the advantage of the hominization method is the lower equipment cost, resulting in lower product costs compared to the ultrasonic method. Compared with previously published studies, the nanoparticle size in this work was smaller. The results showed that one of the two methods above was suitable to prepare nano curcumin with the investigated parameters.

\section{ACKNOWLEDGMENT}

This project is funded by the Department of Science and Technology of Tien Giang Province under Grant no DTYD03/17, 2018-2019.

\section{REFERENCES}


[1]. Ornchuma Naksuriya, Siriporn Okonogi, Raymond M. Schiffelers, Wim E. Hennink ,

Curcumin nanoformulations: A review of pharmaceutical properties and preclinical studies and clinical data related to cancer treatment, Bio. Mat. 35 (2014) pp. 3365-3383

[2]. R. A. Freitas Jr., “What is nanomedicine?” Nanomedicine:Nanotechnology, Biology, and Medicine, vol. 1, no. 1, 2005, pp. 2-9.

[3]. Ahmed, K., Li, Y., McClements, D. J., \& Xiao, H.. Nanoemulsion-and emulsion-based delivery systems for curcumin: encapsulation and release properties. Foo. Chem., 132(2), (2012), pp.799-807.

[4]. R. Raveendran, G. Bhuvaneshwar, and C. P. Sharma, "In vitro cytotoxicity and cellular uptake of curcuminloaded Pluronic/ Polycaprolactone micelles in colorectal adenocarcinoma cells,” J. of Bio. Appli, vol. 27, no. 7, 2013, pp. 811-827.

[5]. S. Mangalathillam, N. S. Rejinold, A. Nair, V.-K. Lakshmanan,S. V. Nair, and R. Jayakumar, "Curcumin loaded chitin nanogels for skin cancer treatment via the transdermal route," Nanoscale, vol. 4, no. 1, 2012, pp. 239-250.

[6]. S. Mandal, C. Banerjee, S. Ghosh, J. Kuchlyan, and N. Sarkar, "Modulation of the photophysical properties of curcumin in nonionic surfactant (Tween-20) forming micelles and niosomes:

a comparative study of different microenvironments," J. Phy. Chem. B, vol. 117, no. 23, 2013, pp. 6957-6968, .

[7]. S. Rahman, S. Cao, K. J. Steadman,M.Wei, and H. S. Parekh, "Native and $\beta$-cyclodextrin-enclosed curcumin: entrapment within liposomes and their in vitro cytotoxicity in lung and colon cancer," Drug Del., vol. 19, no. 7, 2012, pp. 346-353.

[8]. S. Debnath, D. Saloum, S. Dolai et al., "Dendrimer-curcumin conjugate: a water soluble and effective cytotoxic agent against breast cancer cell lines," Anti-Cancer Agents in Med Chem., vol. 13, no. 10, 2013 pp. 1531-1539.

[9]. F. Akhtar, M. M. A. Rizvi, and S. K. Kar, "Oral delivery of curcumin bound to chitosan nanoparticles cured Plasmodium yoelii infected mice,” Biotech. Adv, vol. 30, no. 1, 2012, pp. 310-320.

[10]. V. Kakkar, S. Singh, D. Singla, and I. P. Kaur, "Exploring solid lipid nanoparticles to enhance the oral bioavailability of curcumin,”Mole.r Nutri. and Foo. Res, vol. 55, no. 3, 2011, pp. 495-503.

[11]. Ipar VS, Dsouza A, Devarajan PV, Enhancing Curcumin Oral Bioavailability Through Nanoformulations, Eur. J. Drug. Metab. Pharmacokinet. Feb 15, 2019 ,doi: 10.1007/s13318-019-00545-z. [12]. N.V.Hai, N. T. Cong, L. Q. Tri, N. T. Sang, T. Q. Hieu, Optimizing the process of extracting curcumin from Curcuma Longa L. with the aid of ultrasonic waves, International Conference on Advanced Technology in Food Science and Biotechnology, ISBN: 978-604-67-1137-7,2018, pp 18-30.

[13]. H. Rachmawati, L. Meylina, A. Rahma, and Y. C. Sumirtapur, Size-Dependent of Oil Droplet of Curcumin Nanoemulsion on the In Vivo Release Kinetic of Curcumin After Oral and Intravenous Administrations in Animal Model, Adv. Sci., Eng. and Med., Vol. 6, 2014, pp. 959-964.

[14]. S. Kentish., T. J. Wooster, M. Ashokkumar, S. Balachandran, R.Mawson andL. Simons, The use of ultrasonics for nanoemulsion preparation. Inn. Foo. Sci \& Emer. Tech. 9(2), 2008, 170-175.

[15]. Li, M. K., \& Fogler, H. S. Acoustic emulsification. Part 1. The instability of the oil-water interface to form the initial droplets. J. of Fl. Mech. 88(3), 1978, pp. 499-511.

[16]. D. J .Mc. Clements, Emulsion design to improve the delivery of functional lipophilic components. Ann.Rev. of foo. Sci. and Tech. 1, 2010, pp. 241-269. 
[17]. D. Shailendiran, N. Pawar, A. Chanchal, R.P. Pandey, H. B. Bohidar, andA. K. Verma, Characterization and antimicrobial activity of nanocurcumin and curcumin. In Nanoscience, Technology and Societal Implications (NSTSI), IEEE, 2011 International Conference 2011, pp. 1-7.

[18]. T. P. Sari, B. Mann, R. Kumar, R. R. B. Singh, R. Sharma, M. Bhardwaj, andS. Athira, Preparation and characterization of nanoemulsion encapsulating curcumin. Foo. Hydroc. 43, 2015, pp.540-546.

[19]. G.D. Pangu, D. L. Feke, Acoustically aided separation of oil droplets from aqueous emulsions. Chem. Eng. Sci. 59(15),2004,pp.3183-3193.

[20]. X. Wang, Y. Jiang, Y.W. Wang, M.T. Huang, C. T. Ho, and Q. Huang, Enhancing anti-inflammation activity of curcumin through O/W nanoemulsions. Foo. Chem. 108(2), 2008, pp.419-424.

\section{SO SÁNH KÍCH THỨ̛̛C HẠT NANO CURCUMIN NHŨ TƯƠNG ĐƯợC ĐIỀU CHẾ BĂNG PHƯỚ̉ PHÁP ĐỒNG HÓA VÀ SIÊU ÂM}

Tóm tắt: Trong bài báo này, hệ nano nhũ tương curcumin đã được điều chế thành công bằng cả hai phương pháp đồng hóa và siêu âm. Các điều kiện tối ưu cho phương pháp đồng hóa được thiết lập như sau: nồng độ dầu sachi $2 \%$, nồng độ chất nhũ hóa $3 \%$, công suất 20.000 vòng/phút, thời gian đồng hóa là 60 phút, kích thước trung bình của hệ nano là $78 \mathrm{~nm}$. Trong khi đó, các điều kiện tối ưu của phương pháp siêu âm cũng được xây dựng như sau: nồng độ dầu sachi $2 \%$, nồng độ chất nhũ hóa $2 \%$, công suất siêu âm $450 \mathrm{w} / \mathrm{g}$, tần số $20 \mathrm{kHz}$, kích thước trung bình của giọt nước là $58 \mathrm{~nm}$. Hệ thống nhũ tương nano đã ổn định sau 4 tháng bảo quản lạnh.

Từ khóa: hệ nhũ tương, curcumin, đồng hóa, siêu âm.

Ngày nhận bài: 02/07/2019

Ngày chấp nhận đăng: 01/10/2019 